\title{
Obituary
}

\section{PROFESSOR NEIL F.C. HUDSON}

\author{
1947-20|2
}

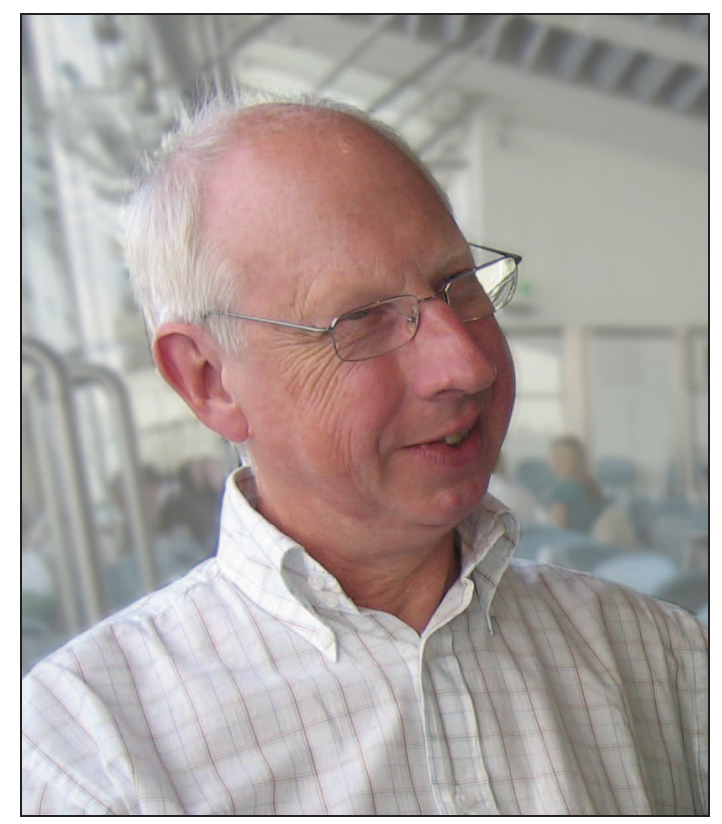

We wish to pay tribute to Neil Hudson, who died aged 65 in November 2012 after a short illness. Neil was a leading academic geologist in metamorphic petrology and structural geology; a Fellow of the Mineralogical Society of Great Britain and Ireland and a Fellow of the Geological Society of London. He was also a member of the Edinburgh Geological Society, the East Midlands Geological Society and the Institute of Learning and Teaching (ILT). He sat on the councils and committees of several of these bodies, and was Chair of the Metamorphic Studies Group (2003-2006).

Born in Edinburgh in 1947, Neil completed his early education at the Royal High School of Edinburgh and read Geology at the University of Edinburgh, graduating in 1970. He continued as a research student at Edinburgh, where one of us $(\mathrm{BH})$ had the pleasure of being his supervisor. $\mathrm{He}$ was awarded a $\mathrm{PhD}$ in 1975, at which time he moved to Derbyshire with his first wife Elspeth, and began a distinguished teaching and research career at Derby College (subsequently University of Derby). He spent the rest of his career at Derby and in 2001 became Professor of Metamorphic Petrology. In 1983 Neil married his second wife Jean, and they lived in Ashbourne until his death. He is survived by: his mother Peggy; both Elspeth and Jean; two children, Pauline and Steven (from his marriage to Elspeth); and three step children Iain, Lorna and Mary. In addition he was the proud grandfather of Anna, Katie, Emma, Tommy, Molly, Alys and Albert; and was looking forward to the arrival of another grandson, Ernie, at the time of his death.

Neil's PhD thesis was entitled: Mineral facies in pelitic rocks with particular reference to the Buchan-type metamorphism of northeastern Scotland. The existence of exceptional prograde metamorphic sequences in the Dalradian rocks of 
Aberdeenshire and Banffshire had initially been recognized by Horne (1884, Mineralogical Magazine, 6), and later became widely known through the publications of Read (1923) and Harker (1932), where the metamorphic sequences involving extensive cordierite and andalusite came to be distinguished under the broad regional name of Buchan metamorphism (Buchan being an old regional name for part of modern Aberdeenshire). Neil's thesis gave the first detailed mineral-chemical data on these sequences, and presented clear interpretations of the metamorphic isograds and reaction sequences.

In general, Neil's research was based on a combination of painstaking field work, characterizing rock types and determining their spatial relationships, together with a clear appreciation of how careful documentation of the compositions of minerals in principal mineral assemblages (chemographic analysis) can lead to precise documentation of metamorphic reaction paths. This in turn led to the determination of metamorphic temperature-pressure conditions and metamorphic history. Thus he continually demonstrated the classic path of going from detailed field observations, to petrological analysis at the fine scale, to the resulting interpretation of major aspects of geological history. He carefully explored all aspects of the metamorphic geology of Aberdeenshire and Banffshire, from the lowest-grade (lowest temperature) rocks to the highest-grade rocks undergoing migmatite formation and melting. In conjunction with colleagues and research students, his work embraced all rock compositions, considering not only the andalusite- and sillimanite-bearing Al-rich pelites, but also Fe-Mg rich cordierite-anthophyllite rocks, and calcsilicate rocks. Thus Neil became the leading authority on the metamorphism and structure of the Dalradian rocks of northeast Scotland, and their place in the evolution of the Caledonian Orogeny.

Neil was always fascinated by rocks and minerals, irrespective of whether this was in the field or sketching out mineral relationships on a piece of paper in the pub or in the class-room. His eye for rocks in the field was excellent. Several geologists from overseas wrote after his death to say what a pleasure it had been to spend time in the field with him. He was always prepared to lead field trips to eastern Scotland for geologists from the UK and overseas, and through such activities developed a research collaboration with
Oulu University, and Pentti Hölttä (of the Finnish Geological Survey). Even geologists who never met Neil, have expressed "appreciation of his contributions to understanding rocks as they really are - in the field". It is symptomatic of his continual enthusiasm, that initial field trips to Anglesey with undergraduate students, led to publications on the deformation history of rocks on Holy Island, Anglesey. Likewise, a conversation on mineral relationships in ultrahigh pressure basic and ultrabasic rocks, enticed him into investigation of mineral reaction relationships across the boundary between the Upper and Lower Mantle at depths of 550 to $800 \mathrm{~km}$.

An important aspect of Neil was that he was always moving forward with his science; he was very able to grasp new ideas and apply them. He was always ready to listen, to talk, to learn and to teach; and was widely appreciated over many years as a lecturer in Derby. Neil always had much time and empathy for his research students (as one of us, SK, well knows). He always listened and paid attention to research students' points of view; he particularly enjoyed sitting and chatting with them in the pub at the end of a day in the field. In all his dealings, Neil was straightforward and honest; and willing to share information at whatever level. As one colleague said on hearing of his death, "he was a true gentleman as well as a scholar." Neil had exacting standards for himself and those he mentored and supervised; his research was always diligent and painstaking. With publications he would be much more concerned about being sure all data were correct and verifiable, and the science well presented, than where the work was to be published.

Neil taught classes at Derby with the same diligence and precision with which he undertook his research. Students commonly find metamorphic phase equilibria and petrogenesis relatively complex, but Neil always showed great patience and humour in his work with undergraduates. He was always innovative and up-todate, and developed computer-based teaching aids on thermodynamic calculation and metamorphic pressure-temperature-time paths. His original practical classes were always challenging yet achievable, and he was a very popular tutor.

Neil was proud of his Scottish roots, retaining a strong connection to his birth city, Edinburgh, where his mother, Peggy, lives. He was frequently drawn back to the landscape and heritage of his native country through his love of walking. Music 
(classical, folk, blues) also formed a big part of Neil's life. As an undergraduate he joined the Folk Song Society, taking up the guitar and developing an interest in the blues, a pleasure he shared with his son, Steven. In later years he formed a duo with his wife Jean, a traditional harpist, and learned to play the wire-strung harp.

Neil took early retirement in 2008 but continued his scientific interests until the end of his life. In the last few months, he worked on the submission of four papers for publication, embracing both the Scottish Highlands and the Lower Mantle. His scientific legacy is surely one which others can admire and build upon.

Ben Harte and Stuart Kearns 